\title{
Probiotic Coating for Ripened Cheeses With Lactobacillus Acidophilus and Lactobacillus Helveticus Inclusion
}

\author{
Paula Martins Olivo \\ Dsc., Animal Science Departament, Maringa State University, 5790 Colombo Avenue, \\ Brazil. E-mail: paulinha_olivo@hotmail.com \\ Mônica Regina da Silva Scapim \\ Professor, Food Engineering Departament, Maringa State University, 5790 Colombo \\ Avenue, Brazil. E-mail: mrsscapim@uem.br
}

Luciana Furlaneto Maia

Professor, Federal University of Technology - Paraná/Brazil (UTFPR), Av. dos Pioneiros, 3131 - Jardim Morumbi, Londrina - PR, 86036-370, Graduate Biological Sciences, Brazil. E-mail: lfmaia2011@gmail.com

\section{Juliana Miazaki}

Dsc. Food Engineering Departament, Maringá State University, 5790 Colombo Avenue, Brazil. E-mail: julianamiazaki@hotmail.com

\section{Bruna Moura Rodrigues}

Msc. Animal Science Departament, Maringá State University, 5790 Colombo Avenue, Brazil. E-mail: bmrodrigues@live.com

\section{Grasiele Scaramal Madrona}

Professor, Food Engineering Departament, Maringa State University, 5790 Colombo Avenue, Brazil. E-mail: gsmadrona@uem.br 
Ferenc Istvan Bankuti

Professor, Animal Science Departament, Maringa State University, 5790 Colombo Avenue, Brazil. E-mail: ferencistvan@gmail.com

Magali Soares dos Santos Pozza (Corresponding author)

Professor, Animal Science Departament, Maringa State University, 5790 Colombo

Avenue, Brazil. E-mail: pozzamagali@yahoo.com.br

Received: Dec. 16, 2019 Accepted: Feb. 1, $2020 \quad$ Published: Feb. 26, 2020

doi:10.5296/jas.v8i3.16052ＵRL: https://doi.org/10.5296/jas.v8i3.16052

\begin{abstract}
Edible films have been employed to improve the food quality. Thus, the objective of this study was to evaluate the edible coverage as a vehicle for probiotics bacteria in cheeses. The experimental design was completely randomized containing four treatments: uncoated cheeses, sodium alginate coated cheeses, sodium alginate + Lactobacillus acidophilus coated cheeses and sodium alginate + Lactobacillus helveticus coated cheeses, analysed for 15 days. The parameters of water steam permeability, thickness and Young's modulus were significant. In the simulation of gastrointestinal conditions, there was a reduction in lactic acid bacteria. There was a reduction in coliform values in coated cheeses. In the identification using Random Amplified Polymorphic DNA technique, Lactobacillus helveticus strains were isolated, suggesting the microorganism migration to inside the cheese. Scanning electron microscopy showed that the lactic acid bacteria were distributed throughout the surface of the edible coating. It suggested the Lactobacillus helveticus permeability added in the cover to the cheese interior, ensuring that the cover can be a vehicle for dairy bacteria.
\end{abstract}

Keywords: lactic acid bacteria, dairy products, mechanical properties, microbiological quality, gastrointestinal simulation

\title{
1. Introduction
}

Cheese is a traditional food that can be made from different types of milk, is diverse in textures, aromas, flavors and shapes, and is part of the regular diet of most people by its composition. Its consumption has increased significantly over the years and, as a result, the cheese industry has evolved, seeking to improve some key product features such as increased shelf life and quality and safety promotion. Some modifications have been highlighted to improve sensory quality such as the inclusion of different packaging systems (Costa, Maciel, Teixeira, Vicente \& Cerqueira 2018).Coatings appear as an environmentally viable alternative for cheese preservation and packaging, acting as individual packaging, but also as an added protection if used in combination with other compounds. The use of edible packaging and coating materials 
has been explored as a possibility because, like conventional coating materials, they allow the deterioration prevention, the shelf life extension and the water loss reduction. Acting as antimicrobial agents and bring several advantages over conventional coatings, such as better spreading, diffusivity and solubility (Ramos et al., 2012). Probiotic microorganisms can be used as a solution to improve cheese composition quality and shelf life. They are defined as living microorganisms that, when administered in adequate amounts, confer a benefit on the host's health (Food and Agriculture Organization, 2001; Sanders, 2003). The recommendation in foods to be beneficial to humans is to be present in the amount of $10^{6}$ live microorganisms per $\mathrm{g}$ or $\mathrm{mL}$ at the time of consumption (Chapel, Hay, \& Shah, 2006, Mokarram, Mortazavi, Najafi \& Shahidi 2009, Picot \& Lacroix, 2004, Manojlović, Nedović, Kailasapathy \& Zuidam, 2010). Lactic bacteria (LAB) are the most commonly studied probiotics in recent decades. Belonging to desirable gastrointestinal tract microflora (TGI) they are therefore "considered safe" (Sanders, 2003) and are involved in the fermentation of most dairy products such as cheese and yogurt. They play an essential role in food preservation and inhibit spoilage microorganisms or foodborne pathogens by producing lactic acid, acetic acid, $\mathrm{H}_{2} \mathrm{O}_{2}$, bacteriocin, diacetyl and $\mathrm{CO}_{2}$ (Yuksekdag \& Aslim, 2010). The objective of this study was to evaluate the probiotic coating as a vehicle for lactic acid bacteria Lactobacillus acidophilus ( $L$. acidophilus) and Lactobacillus helveticus (L. helveticus) in the ripening cheese process. Microbiological stability, viability, resistance to gastrointestinal tract passage, cell morphology by electron scanning microscope (SEM) and intrinsic coating properties were evaluated.

\section{Material and Methods}

\subsection{Cheese Production and Edible Coating}

The experiment was carried out at the Milk Quality laboratory (Mesoregional Center for Excellence and Milk Technology, UEM/Brazil). The cheeses were produced with raw milk, without pasteurization process and ripened for 15 days, each cheese had $500 \mathrm{~g}$ and circular shape. The cheeses were then subjected to the four treatments: uncoated cheeses (SEMc), sodium alginate (AG) coated cheeses, sodium alginate and L. acidophilus (0.001\%) (AGLA) coated cheeses and cheeses coated sodium alginate and L.helveticus (0.001\%) (AGLH). During the analyzes the cheeses were kept in a B.O.D. for 15 days / $12^{\circ} \mathrm{C}$ and relative humidity of $\pm 60.5 \%$. For the edible coating (filmogenic solution) the procedure was performed by solubilization of $2 \%$ sodium alginate macromolecules and $2 \%$ calcium chloride in sterile water. Lyophilized cultures of L. acidophilus and L. helveticus (SACCO®) were activated in sterile MRS agar (Himedia) both at $37^{\circ} \mathrm{C}$ for 24 hours. After this period they were centrifuged (6000 rpm for 15 minutes) and the precipitates were washed with sterile distilled water and centrifuged again (2 times), resuspended in sterile distilled water and added to the coating (Liserre, Re \& Franco, 2007 ), $1 \mathrm{~mL}$ of the concentrate was used for each $1000 \mathrm{ml}$ of sodium alginate solution. After this step, the coating was applied to the cheese samples by dipping. 


\subsection{Cheese Analysis and Edible Coating}

\subsubsection{Physico-Chemical and Microbiological Analysis}

The count $(\mathrm{CFU} / \mathrm{mL})$ was determined by deep sowing on $\mathrm{MRS}$ agar $\left(35^{\circ} \mathrm{C} / 48\right.$ hours).In cheese samples, at 0, 5, 10 and 15 storage days, water activity (Aqualab®) 4TE, Decagon, São Paulo, Brazil), $\mathrm{pH}$ (digital $\mathrm{pH}$ meter, Tecnal Tec-5) and titratable acidity were determined (Lutz, 2008).For microbiological analyzes, samples were diluted in peptone water and lactic acid bacteria (MRS Himedia-De Man, Rogosa and Sharpe agar) were evaluated and for coliforms seeded on VRB agar (Himedia - Violet Reb Bile Agar), incubated at $35^{\circ} \mathrm{C}$ for 48 hours (AOAC, 1992).

\subsubsection{Edible Coating Properties}

To characterize the coating hygroscopic behavior and mechanical properties, the filmogenic solution was deposited in suitable containers (rectangular shaped acrylic plates containing $150 \mathrm{ml}$ gel) and oven dried at $60^{\circ} \mathrm{C}$ for 24 hours.For the coverage evaluations, the following analyzes were performed: coating thickness evaluation, mechanical property (tensile test), water steam permeability (SP), adsorption isotherm and scanning electron microscopy (SEM).The coating thickness was evaluated manually using a digital micrometer (Mitutoyo, resolution $0.01 \mathrm{~mm}$ - São Paulo - SP). For tensile properties determination, the samples were conditioned at $53 \%$ relative humidity at $25^{\circ} \mathrm{C}$ for three days in B.O.D. Tensile properties were determined using a Stable MicroSystemtexturometer (TAXT2i model - England) using a methodology based on the American Society for Testing and Material ASTM (1996). The tensile properties determined were: maximum tensile strength at break (MPa), elongation at break (\%) and elastic modulus (MPa). Steam vapor permeability was determined gravimetrically according to the American Society for Testing and Material (1995) method with some modifications. The relative humidity gradient used was $2-53 \%$ at $25{ }^{\circ} \mathrm{C}$, where samples fixed in aluminum capsules were weighed until the mass gain rate was constant. For sorption isotherm analysis, samples of about $0.5 \mathrm{~g}$ were conditioned for 20 days in anhydrous calcium chloride, after the drying period the samples were evaluated in different desiccators containing $11.3 \%$ (sodium chloride), 33\% (magnesium chloride), 43\% (potassium carbonate), $53 \%$ (magnesium nitrate), 64\% (sodium nitrate), 75\% (sodium chloride), 84\% (potassium chloride) and $90 \%$ (barium chloride). For isotherm modeling, the Guggenheim model Anderson-de-Boer were used (GAB) (Takahashi et al, 2017).

\subsubsection{Resistance to Passage Through the Gastrointestinal Tract}

Microorganisms were also tested for resistance to passage through the gastrointestinal tract on days 0 and 15 of storage, following the methodology described by Rao et al. (1989) in which $1 \mathrm{~g}$ of cheese from treatments containing microorganism (AGLA and AGLH) were weighed and placed in a tube containing $10 \mathrm{~mL}$ of simulated gastric juice $(0.08 \mathrm{M} \mathrm{HCl}$ containing $0.2 \% \mathrm{NaCl}, \mathrm{pH} 1.55$ ) and incubated. at $37^{\circ} \mathrm{C}$ for $120 \mathrm{~min}$. After incubation, the samples were removed and placed in $9 \mathrm{~mL}$ of simulated intestinal juice $\left(0.05 \mathrm{M} \mathrm{KH}_{2} \mathrm{PO}_{4}, \mathrm{pH}\right.$ 7.43). The tubes were incubated at $37^{\circ}$ for $150 \mathrm{~min}$. At the incubation end, $1 \mathrm{ml}$ of each vial was used for microbiological analysis, and $1 \mathrm{ml}$ of each solution was added to test tubes 
containing $9 \mathrm{ml}$ of $0.1 \%$ homogenized peptone water, followed by serial dilutions of inoculated in MRS agar.

\subsubsection{Random Amplified Polymorphic DNA (RAPD)}

To verify the $\mathrm{LAB}$ migration of the edible cover inside the cheese, colonies isolated from both treatments were subjected to purification and confirmed by Gram stain. Then the bacterial isolates were genotypically analyzed using the Random Amplified Polymorphic DNA (RAPD) technique and the OPM1 primer (5'GTTGGTGGCT3 '). The RAPD product was analyzed on $1.5 \%$ agarose gel containing ethidium bromide $(0.5$ g.ml-1) and analyzed by the L-PIX ST (LOCCUS) photo documentation apparatus.The RAPD profiles obtained by using the two oligonucleotides were combined in a matrix and compared using the Jaccard coefficient; The coefficients correlation was calculated by the Unweighted pair-group method with arithmetical averages (UPGMA) through the Numerical taxonomy system of multivariate programs (RoTS, 2000).

\subsubsection{Scanning Electron Microscopy}

For coatings microstructure analysis by electron microscopy, the Quanta 250 Electron Scanning Microscope (Fisher Scientific-FEI, Oregon, USA) was used. The previously prepared coating was frozen in liquid nitrogen $\left(-196^{\circ} \mathrm{C}\right)$ after, the samples were lyophilized for 24 hours, prepared in the stub with the thin layer of gold deposition and evaluated under magnifying glass 500 and 1000 times.

\subsubsection{Statistical Analysis}

Data were analyzed using the SAS REG Proc 9.3 (2013).

\section{Results and Discussion}

\subsection{Edible Coating Properties}

Due to the absence of the use of filmogenic solution, the cheeses (SEMc) were not analyzed. There was a significant difference $(\mathrm{p}<0.05)$ for Young's modulus $(\mathrm{MPa})$ of the coatings being the highest value for the treatment containing only sodium alginate, the LAB cells presence decreased on average the Young's modulus (Table 1).

Table 1. Characterization of sodium alginate coatings and containing microorganisms

\begin{tabular}{llll}
\hline Parameters & AG & AGLA & AGLH \\
\hline Rupture stress $(\mathrm{MPa})$ & $16.192 \pm 7.4391$ & $17.025 \pm 3.7982$ & $18.100 \pm 2.950$ \\
Elongation $(\%)$ & $5.1950 \pm 1.9197$ & $5.2883 \pm 2.129$ & $5.2960 \pm 1.551$ \\
Young' modulus $(\mathrm{MPa})$ & $22.794^{\mathrm{a}} \pm 12.324$ & $6.534^{\mathrm{b}} \pm 4.068$ & $5.976^{\mathrm{b}} \pm 1.264$ \\
RHG gradient $(\%)$ & $2-53$ & $2-53$ & $2-53$ \\
SP $\left(\times 10^{-15}\right)(\mathrm{g} / \mathrm{m} . P a . s)$ & $1.017^{\mathrm{c}} \pm 1.851$ & $4.716^{\mathrm{b}} \pm 1.362$ & $6.046^{\mathrm{a}} \pm 5.258$ \\
Thickness $\left(\mathrm{x} 10^{-3}\right)(\mathrm{m})$ & $0.0798^{\mathrm{a}} \pm 0.0177$ & $0.0398^{\mathrm{b}} \pm 0.0069$ & $0.0046^{\mathrm{c}} \pm 0.0004$ \\
\hline
\end{tabular}


* AG: sodium alginate coating; AGLA: sodium alginate + L. acidophilus coating and AGLH: sodium alginate $+L$. helveticus coating; the means followed by the same letters in the line did not differ significantly by the ANOVA and Tukey tests, with a significance level of 5\%; RHG: relative humidity gradient; SP: water steam permeability.

The edible cover thickness values were significantly different $(\mathrm{p}<0.005)$. However, Soukoulis, Behboudi-Jobbehdar, Yonekura, Parmenter, \& Fisk (2014) found no significant effect on thickness by the Lactobacillus rhamnosus GG cells addition to prebiotic fibers. Thickness can be considered as an important parameter that determines factors such as coating transparency, water steam permeability and mechanical properties, improving the coating capacity in relation to the food mechanical integrity (Ghanbarzadeh \& Almasi, 2011).In the cover ability to elongate, no significant difference was observed for values obtained between the treatments. Coverage treatment containing sodium alginate tended to increase Young's modulus (22.704 $\mathrm{MPa}$ ) and decrease tensile strength, a behavior already observed in the literature on polysaccharide and protein coatings (Jo, Kang, Lee, Kwon\& Byun, 2005). In the other coverings with microorganism inclusion, there was increased tensile strength and decreased Young's modulus, thus reducing the coatings flexibility. In the study by Pereira et al. (2016), the probiotic microorganism incorporation in coatings led to a slight decrease in the rupture stress parameter value, similar results were also obtained by Kanmani and Lim (2013), through the probiotic microorganism addition in the pullulan and starch coatings that resulted in breaking stress reduction. In the Aziz, Salama, \& Sabaa (2018) study in which they used sodium alginate and different castor oil $(0,1,2$ and $3 \%)$ percentage to produce antimicrobial coverage and to evaluate mechanical properties, values, the values for treatment containing only sodium alginate were for breaking stress (MPa) $17.35 \pm 4.36$, elongation (\%) $10.04 \pm 5.10$ and Young's modulus (MPa) $33.73 \pm 0.79$ higher than those found in this study. There was a significant difference for water steam thickness and permeability, being the highest thickness values in the treatment containing sodium alginate and the highest permeability value presented in the treatment of sodium alginate and L. helveticus.

Water steam permeability (SP) values refer to the transfer of water from food to the environment or from the environment to food; coverings should have a lower SP to reduce food dehydration as much as possible and thus keep them fresh (Gontard, Guilbert \& Cuq, 1993). The lowest SP value was observed for treatment without microorganism inclusion and with higher coverage thickness. Ebrahimi et al. (2018) observed SP increase of up to $50 \%$ by the probiotic addition (Lactobacillus acidophilus, Lactobacillus casei, Lactobacillus rhamnosus and Bifidobacterium bifidum), compared to the coverage of carboxymethyl cellulose - CMC, without microorganisms. Sánchez-González, Saavedra \& Chiralt (2013) evaluated different polysaccharides and proteins for edible coverings with the Lactobacillus plantarum microorganism inclusion, found that the lactic acid bacteria incorporation induced a significant increase in SP, regardless of the hydrocolloid nature. It could be justified by the bacteria presence that introduces discontinuities in the polymeric matrix, and could promote the mass transfer of water molecules, corroborating the data found in this experiment. Ma, Jiang, Ahmed, Quin \& Liu (2019) also verified that the addition of Lactococcus lactis can change the spatial structure of the molecules, destroy intermolecular interactions, and enlarge the intermolecular 
space, thereby directly increasing SP which could decrease product shelf life, since higher porosity decreases barrier property. Therefore, the presence of cells may cause discontinuity in the cover matrix. Water vapor permeability occurs through solubility and diffusion, the presence of pores in the film matrix favors mass transfer, facilitating the diffusion of molecules in water. In the Gialamas, Zinoviadou, Biliaderis \& Koutsoumanis (2010) study, the Lactobacillus sakei cells inclusion in sodium alginate and calcium chloride coatings was evaluated to determine mechanical and chemical properties. The average values for coat adsorption isotherm showed no significant difference $(p>0.05)$ for the evaluated parameters (Table 2).

Table 2. Values of GAB equation constants at $25^{\circ} \mathrm{C}$, calculated by nonlinear regression for sodium alginate and microorganisms

\begin{tabular}{llll}
\hline Parameters & AG & AGLA & AGLH \\
\hline $\mathrm{m}_{0}$ & 0.18646 & 0.01358 & 0.01741 \\
$\mathrm{C}$ & 0.81829 & 0.91831 & 4.48303 \\
$\mathrm{~K}$ & 0.26688 & 0.77635 & 0.69275 \\
$\mathrm{R}^{2}$ & 0.97860 & 0.91320 & 0.94810 \\
\hline
\end{tabular}

* AG: sodium alginate coating; AGLA: sodium alginate + L. acidophilus coating and AGLH: sodium alginate $+L$. helveticus coating; Mo: water content of the monolayer; C: Guggenheim constant; K: measure of the water sorption heat in the multilayers.

Figure 1 show the isotherms, they are sigmoid, and it is observed that the moisture content of the coating slowly increased with increasing humidity up to $\alpha \mathrm{w} \sim 0.64$.
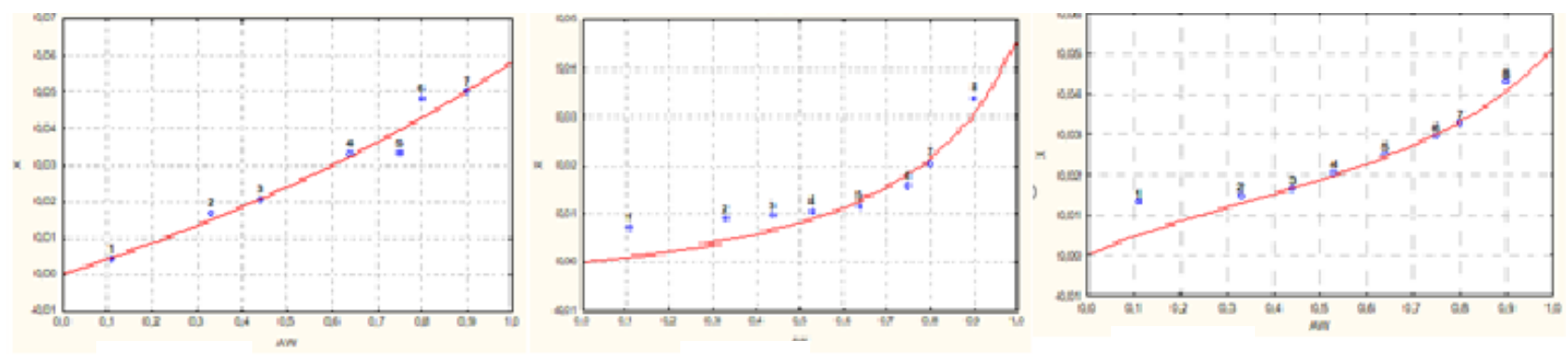

Figure 1. Moisture sorption isotherm obtained for sodium alginate, sodium alginate and $L$. acidophilus and sodium alginate and L. helveticus coating

The coating water sorption isotherm behavior was not affected by culture presence in any of the methods used for bacterial cell incorporation (casting and by aspersion), which can be attributed to the fact that the added content is smaller compared to the coating dry matter and, 
in this sense, it is not expected to influence the coating water sorption isotherm behavior.

\subsection{Physico-Chemical and Microbiological Analysis}

The lactic acid bacterial (LAB) count values at the zero time of evaluation showed that there was an initiating microbiota in both coated and uncoated cheeses having the highest value in treatments for cheese with sodium alginate and L. acidophillus (Table 3), so the coating presence may favor the growth or survival of these bacteria, reducing oxygen permeability and increasing Aw, factors that would limit their growth in uncoated cheese (Ramos et al., 2012).

Table 3. Physico and microbiology composition of cheeses with and without film application

\begin{tabular}{|c|c|c|c|c|c|c|c|c|c|c|c|c|}
\hline \multirow{2}{*}{ Variables } & \multicolumn{4}{|c|}{ Treatments } & \multicolumn{5}{|l|}{ Time } & \multicolumn{3}{|l|}{ P-value } \\
\hline & SEMc & AG & AGLA & AGLH & 0 & 5 & 10 & 15 & SEM & Treat & Time & Treat*Time \\
\hline $\mathrm{pH}$ & $5.6483 \pm 0.1253^{\mathrm{a}}$ & $5.5458 \pm 0.1366^{\mathrm{b}}$ & $5.4933 \pm 0.1489^{\mathrm{b}}$ & $5.5541 \pm 0.1876^{\mathrm{b}}$ & $5.7500 \pm 0.0969$ & $5.5708 \pm 0.0697$ & $5.5141 \pm 0.0952$ & $5.4066 \pm 0.1210$ & 0.0226 & 0.0001 & $<.0001$ & 0.0572 \\
\hline Acidity $\left({ }^{\circ} \mathrm{D}\right)$ & $27.583 \pm 0.635^{\mathrm{ab}}$ & $24.833 \pm 0.5890^{\mathrm{b}}$ & $27.416 \pm 0.5664^{\mathrm{ab}}$ & $28.666 \pm 1.025^{\mathrm{a}}$ & $18.833 \pm 0.3639$ & $29.916 \pm 0.4737$ & $31.583 \pm 0.8039$ & $28.166 \pm 0.3785$ & 0.1038 & 0.0170 & $<.0001$ & $<.0001$ \\
\hline Wateractivity & $0.8017 \pm 0.0141^{\mathrm{c}}$ & $0.8245 \pm 0.0230^{\mathrm{b}}$ & $0.8260 \pm 0.0207^{\mathrm{b}}$ & $0.8470 \pm 0.0477^{\mathrm{a}}$ & $0.8407 \pm 0.0446$ & $0.8437 \pm 0.0240$ & $0.8153 \pm 0.0201$ & $0.7995 \pm 0.0107$ & 0.0004 & $<.0001$ & $<.0001$ & $<.0001$ \\
\hline Coli (Log 10$)$ & $7.0390 \pm 0.9445$ & $6.9995 \pm 0.9907$ & $7.1353 \pm 0.6107$ & $7.0210 \pm 0.7274$ & $7.6107 \pm 0.2544$ & $7.0585 \pm 0.2281$ & $7.7008 \pm 0.3589$ & $5.8250 \pm 0.3163$ & 0.0116 & 0.0710 & $<.0001$ & $<.0001$ \\
\hline $\operatorname{LAB}(\log 10)$ & $7.4943 \pm 0.7004^{\mathrm{ab}}$ & $7.2975 \pm 0.7645^{\mathrm{ab}}$ & $7.7121 \pm 1.1636^{\mathrm{a}}$ & $7.2169 \pm 0.7946^{\mathrm{b}}$ & $8.3334 \pm 0.5117$ & $6.7945 \pm 0.6623$ & $7.9646 \pm 0.6822$ & $6.9126 \pm 0.4802$ & 0.1277 & 0.0135 & $<.0001$ & $<.0001$ \\
\hline
\end{tabular}

* LAB: lactic acid bacteria; SEMc: uncoated; AG: sodium alginate coating; AGLA: sodium alginate + L. acidophilus coating and AGLH: sodium alginate + L. helveticus coating; Coli: coliforms; SEM: standard error of mean, Treat: Treatment, P-value $<0.05$. Regressionequations: Acidity: SEM: $y=-0.02178 \mathrm{x} 2+0.38222 \mathrm{x}+2.133333 \mathrm{R} 2: 0.7262$; AG: $\mathrm{y}=-0.02200 \mathrm{x} 2+0.40333 \mathrm{x}+1.63333 \mathrm{R} 2=0.9633 ;$ AGLA: $\mathrm{y}=0.05667 \mathrm{x}+2.31667 \mathrm{R}^{2}$ : 0.3412; AGLH: $\mathrm{y}=-0.02933 \mathrm{x} 2+0.53867 \mathrm{x}+1.3933 \mathrm{R}^{2}: 0.8735$; Wateractivity: AG: $\mathrm{y}=$ $-0,0008933 \mathrm{x} 2+0,01220 \mathrm{x}+0.81933 \mathrm{R}^{2}: 0.8735$; AGLA: $\mathrm{y}=-0.00056000 \mathrm{x} 2+0.00661 \mathrm{x}+$ 0.82540 R2: 0.7494; AGLH: $\mathrm{y}=-0.00793 \mathrm{x}+0.90650 \mathrm{R}^{2}: 0.9408 ; \mathrm{pH}:$ SEMc: $\mathrm{y}=$ 0.00342x2-0.07044x + 5.83667 R2: 0.9011; AG: $-0.02114 x+5.65433$ R2: 0.7792; AGLA: $y$ $=-0.02147 \mathrm{x}+5.65433 \mathrm{R} 2: 0.7792 ;$ AGLH: $\mathrm{y}=-0.02953 \mathrm{x}+5.77567 \mathrm{R} 2: 0.8411 ; \mathrm{VRB}:$ SEMc: $y=-0.01049$ x $2+0.04242 x+7.29702$ R2: 0.9996; AG: $y=-0.13898 x+7.60338 R 2$ : 0.9600; AGLH: $y=-0.0085 x 2+0.01653 x+7.6943$ R2: 0.8963; MRS: SEM: $y=0.01935$ $\mathrm{x} 2-0.37020 \mathrm{x}+0.35015 \mathrm{R} 2: 8503 ; \mathrm{AG}: \mathrm{y}=-0.10171 \mathrm{x}+7.97561 \mathrm{R} 2: 0.7744 ;$ AGLH: $\mathrm{y}=$ $0.01853 \times 2-0.32457+8.02947 \mathrm{R} 2: 0.48$.

Higher counts were also found at 10 days of storage for the LAB presence in the cheeses of referred treatment. According to Perreira et al. (2016) evaluating two different microorganisms inclusion and their viability in different storage times at different temperatures, 
Bifidobacterium animalis $\mathrm{Bb}-12 \AA$ and Lactobacillus casei-01, whey protein isolate coating by $0,3,5,10,40$ and 60 days at 23 and $4{ }^{\circ} \mathrm{C}$, observed that from the initial concentration of $10^{9}$ $\mathrm{CFU} / \mathrm{g}$ coating, a viability loss of $3 \log$ cycles (reaching $10^{6} \mathrm{CFU} / \mathrm{g}$ ) was observed within 10 days of storage at $23{ }^{\circ} \mathrm{C}$ for both probiotics and was kept stable thereafter, with slight reduction after 40 days of storage. In Ningtyas, Bhandari, Bansal \& Prakash (2019) study, the survival of Lactobacillus rhamnosus encapsulated with sodium alginate and free in cream cheese mass was studied during 35 days of storage at $4{ }^{\circ} \mathrm{C}$. Both treatments and storage days ranged from 8.28 to $6.63 \log \mathrm{CFU} / \mathrm{g}$ respectively, effectively showing that the encapsulation may be a more effective way for microorganism survival. Ramos et al. (2012) developed different edible coverings based on whey protein isolate, glycerol, guar gum, sunflower oil and Tween 20 along with various antimicrobial compounds combinations. Edible covering made with antimicrobials, lactic acid and COS (chitosan oligosaccharide) use in "Saloio" semi-hard ripened cheeses showed a protective effect against spoilage and pathogenic microorganisms (Staphylococcus spp., Enterobacteriaceae, Pseudomonas spp.) increasing the cheese shelf life and conserving it for up to 60 days. The highest average values were observed for total coliforms presence (VRB) for uncoated cheeses at 10 days (Figure 2). At 15 days, values in both coated and uncoated treatments decreased by about 2 logs during storage. The highest coliforms value on day zero of storage and their decrease during storage may summarize the idea that this contamination could come from milk used for cheese production due to the pasteurization absence (Zottola \& Smith, 1993).

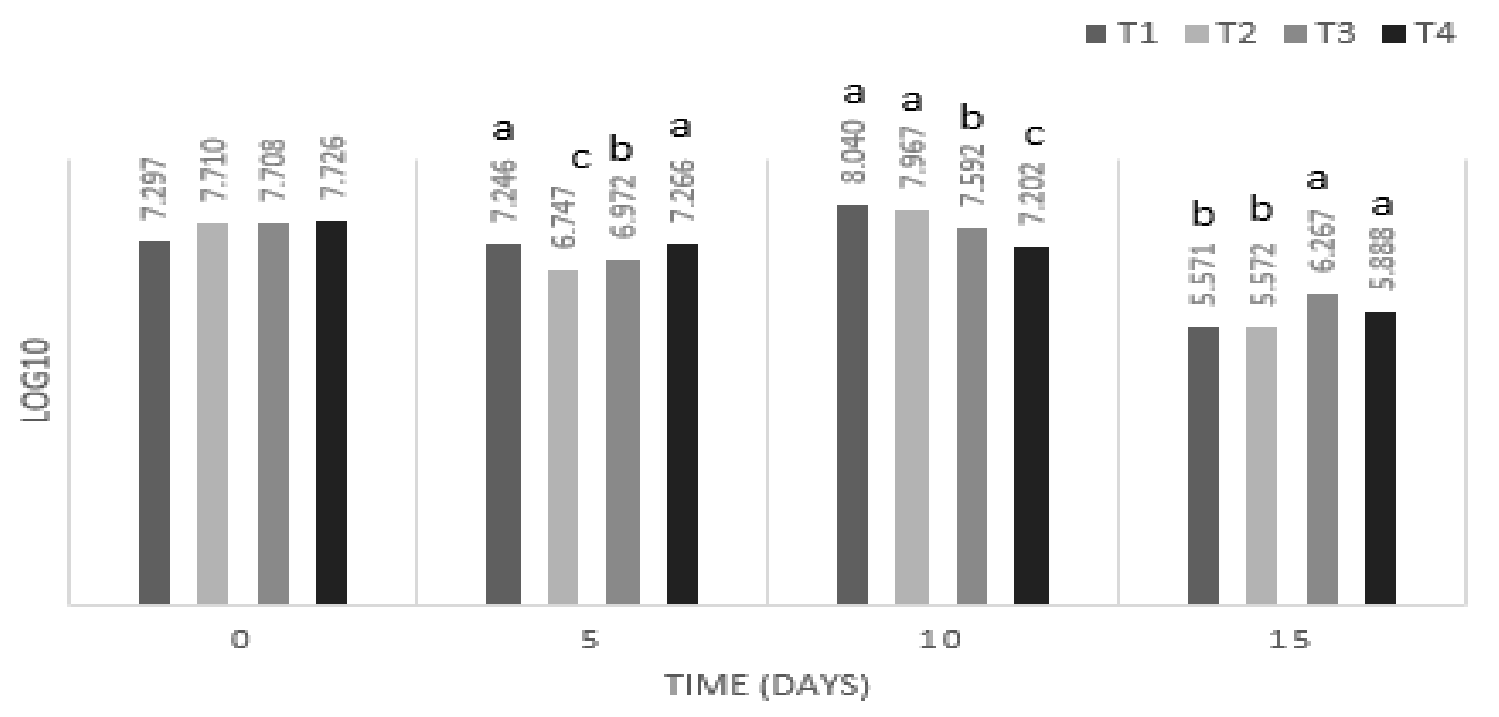

Figure 2. Unfolding of the interactions of treatments and times for counts of coliforms on cheeses

T1: withoutcoating; T2: sodium alginate coating; T3: sodium alginate coating $+L$. acidophilus and T4: sodium alginate coating + L. helveticus 


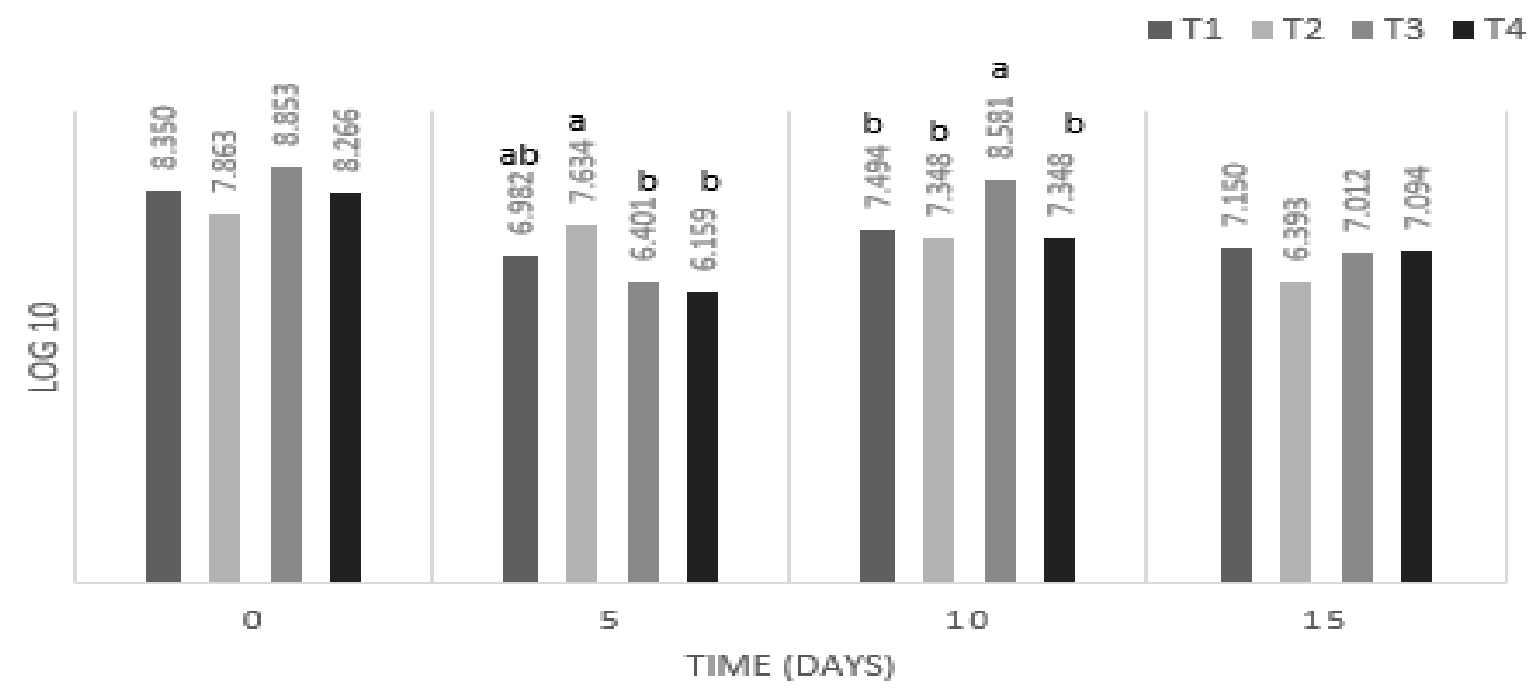

Figure 3. Unfolding of the interactions of treatments and times for counts of lactic acid bacteria on cheeses

T1: withoutcoating; T2: sodium alginate coating; T3: sodium alginate coating $+L$. acidophilus and T4: sodium alginate coating + L. helveticus

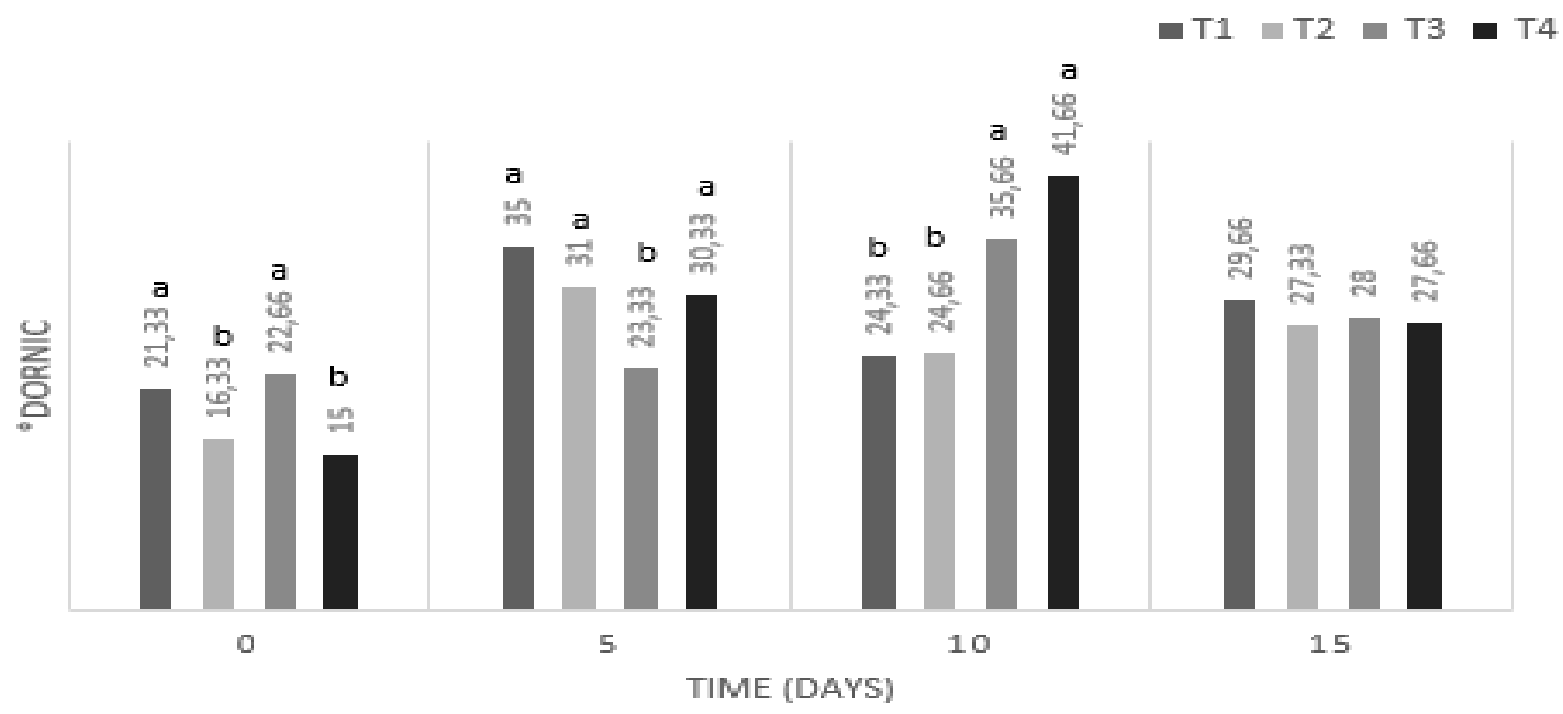

Figure 4. Unfolding of the interactions of treatments and times, for acidity ( ${ }^{\circ}$ Dornic) on cheeses

T1: withoutcoating; T2: sodium alginate coating; T3: sodium alginate coating $+L$. acidophilus and T4: sodium alginate coating + L. helveticus 


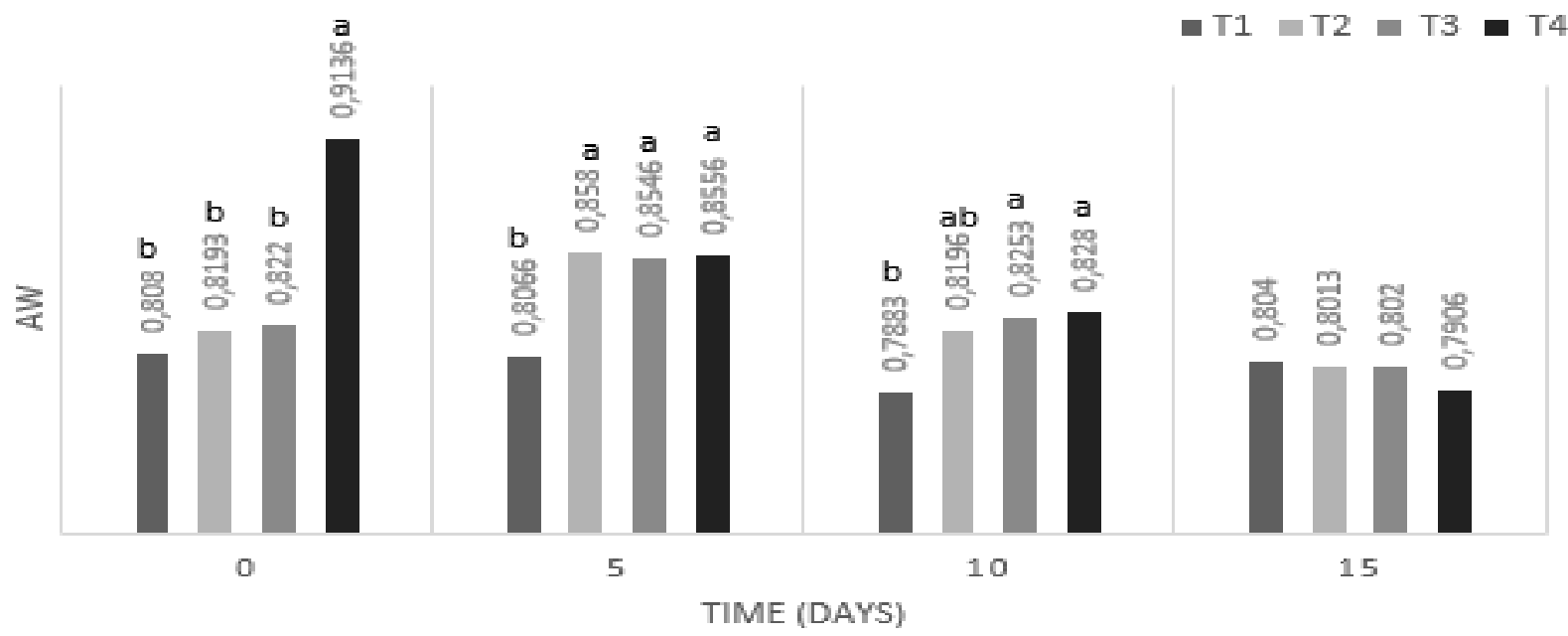

Figure 5. Unfolding of the interactions of treatments and times, for water activity on cheeses

T1: withoutcoating; T2: sodium alginate coating; T3: sodium alginate coating $+L$. acidophilus and T4: sodium alginate coating + L. helveticus

T1 T2 T3 $\square \mathrm{T}$ T3

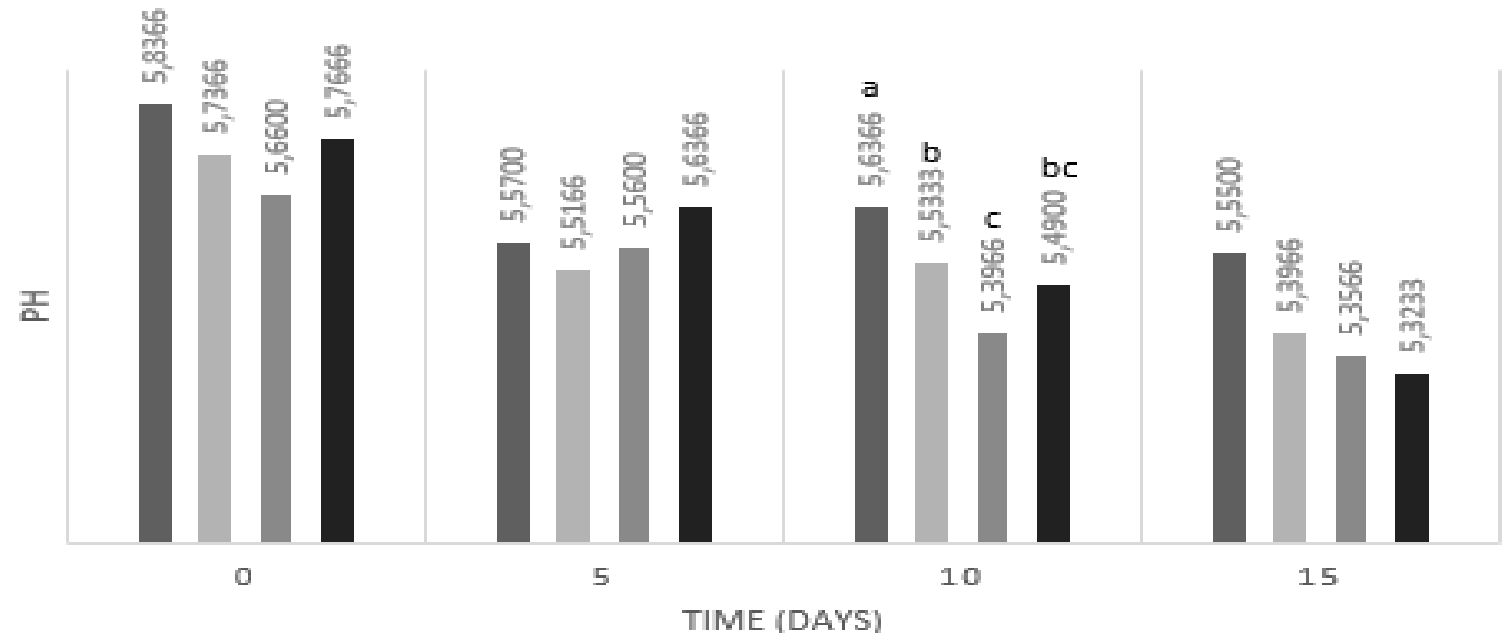

Figure 6. Unfolding of the interactions of treatments and times, for $\mathrm{pH}$ on cheeses T1: withoutcoating; T2: sodium alginate coating; T3: sodium alginate coating $+L$. acidophilus and T4: sodium alginate coating + L. helveticus

At 10 days of storage the highest $L$. acidophilus counts $(8.58 \mathrm{log})$ led to a decrease in the coliform counts (7.59 log) (Figure 3), probably due to the increase in lactic acid production (Figure 4) (Fathollahi, Hesari, Azadmard, \& Oustan, 2010).At 10 days the highest pH values between treatments was observed in cheese without the use of edible coating (5.64) and was statistically different for the other treatments with coating inclusion (Figure 6). However, Kanmani \& Lim (2013) studied starch coatings with the probiotic strains inclusion and did not observe differences in $\mathrm{pH}$. The water activity ( $\mathrm{Aw}$ ) was significant for the treatments $(\mathrm{p}<0.05)$ and also for the storage time (Figure 5). Ramos et al. (2012) evaluated the effectiveness of 
antimicrobial edible coatings in cheese coverage over 60 storage days and realized that Aw was not constant over storage time for coated and uncoated cheeses, and that only after 20 days of storage could the surface reach equilibrium with the surrounding atmosphere. In this experiment the values stabilized at the $10^{\text {th }}$ day of storage, and the lowest value was observed for uncoated cheese (0.8017), so it can be said that there was higher water loss in uncoated cheese. Cheeses are presented as an alternative vehicle to maintain sufficient viable probiotic bacteria after passage through the gastrointestinal tract in order to promote human health (Burns et al., 2008). Cheeses have a higher $\mathrm{pH}$ than yogurt and milk which can help maintain probiotic viability during storage and improve their buffering capacity. Capacity in combination with high protein lipid dense matrix may offer additional protection to microbial cells during passage through the stomach to the intestine (Cruz, Buriti, de Souza, Faria, \& Saad, 2009; Hayes, Coakley, O'sullivan, \& Stanton, 2006; Phillips, Kailasapathy, \& Tran, 2006).

\subsection{Resistance to Passage Through the Gastrointestinal Tract}

There was a decrease in $\mathrm{LAB}$ count at different evaluation times in relation to gastric simulation. With a reduction of $5.78 \mathrm{log}$, not being considered resistant to the microorganism passage through the gastrointestinal tract. (Table 4). For gastrointestinal simulation, treatments containing L. acidophilus (AGLA) and L. helveticus (AGLH) were evaluated at 0 and 15 days (Table 5).

Table 4. Lactobacillus count $\left(\log _{10}\right)$ in relation to gastrointestinal resistance of microorganisms at 0 and 15 days

P-value

Variables

AGLA

AGLH 0

SEM Treat Time

Treat*time

$\begin{array}{lllllllll}\text { SG } & 2.190 \pm 0.432 & \begin{array}{l}2.247 \pm \\ 0.416\end{array} & 2.554 \pm 0.0667 & 1.877 \pm 0.333 & 0.4329 & 0.6089 & <.0001 & 0.4508\end{array}$

*AGLA: sodium alginate + L. acidophilus coating and AGLH: sodium alginate $+L$. helveticus coating. SEM: standard error of mean, P-value $=0.05$. AGLA regression equations: $\mathrm{y}=0.04103 \mathrm{x}+1.926 \mathrm{R} 2: 0.5329 ;$ AGLH: $\mathrm{y}=0.05107+1.8100 \mathrm{R} 2: 0.8969 ;$ SG: gastric simulation.

The values observed by Oliveira et al. (2014) for viable cell count of Lactobacillus acidophilus (LA-5), Lactobacillus caseisubsp. paracasei (L. casei-01) and Bifidobacterium. lactis (BB 12) incorporated in goat cheese after exposure to simulated gastrointestinal conditions showed significant differences between the treatments $(\mathrm{P}<0.05)$. At the beginning of in vitro digestion, all evaluated probiotic strains incorporated into cheese had viable cell counts between 7 and 8 $\log$ CFU / g; however, samples obtained at the end of in vitro digestion showed a viable cell count of $6.0 \log \mathrm{CFU} / \mathrm{g}( \pm 0.25)$ for L. acidophilus, $5.7 \log \mathrm{CFU} / \mathrm{g}( \pm 0.19)$ for L. casei subsp. paracaseiand $5.5 \log \mathrm{CFU} / \mathrm{g}( \pm 0.21)$ for B. lactis, decreasing its survival as it passes through the gastrointestinal tract. According to Dos Santos et al. (2015) evaluating eight Lactobacillus rhamnosus and Lactobacillus plantarum strains isolated from manufactured rennet cheese 


\section{I Macrothink}

Journal of Agricultural Studies

ISSN 2166-0379

2020, Vol. 8, No. 3

observed a reduction close to or greater than $50 \%$ at the end of the in vitro assay, a reduction of $2.46 \log \mathrm{CFU} / \mathrm{mL}$ at the end of the assay, starting from an initial inoculum of $9.10 \log \mathrm{CFU} /$ mL.In the Eckert et al. (2018) study some probiotic lactic acid bacteria, Lactobacillus plantarum ATCC8014, Lactobacillus paracasei ML33 and Lactobacillus pentosus ML82, were encapsulated with serum-alginate pectin (WAP) or permeated serum-alginate-pectin (PAP) to verify resistance to the gastrointestinal tract and storage conditions. Some Lactobacillus strains are unable to survive at low $\mathrm{pH}$ values because these conditions inhibit the metabolic activity of them, thereby reducing its viability (Sultana et al., 2000). The results showed that non - encapsulated microorganisms are more sensitive to simulated gastric conditions since none of the isolates survived these conditions, reducing 3 log cycles and maintaining the viability of $6 \log \mathrm{UFCmL}^{-1}$ ).

\subsection{Random Amplified Polymorphic DNA (RAPD)}

Cheeses containing microorganisms added to the coating were analyzed by the RAPD-PCR technique to verify the bacterial migration capacity of the surface into the cheese. The RAPD-PCR reveals the diversity and dynamics of some lactic acid bacteria strains, which have been useful to identify the presence of some microorganisms in complex environments such as cheese (Lazzi et al., 2009; Mancini, Lazzi, Bernini, Neviani, \&Gatti, 2012; Randazzo, Caggia, \& Neviani, 2009).According to Figure 7, that show some isolates obtained from the cheese interior (Lh, T3-AGLA and T4-AGLH) belong to the same species, since they are $100 \%$ similar. The similarity percentage between Lactobacillus acidophilus (La) and T3 (AGLA) strains was $20 \%$, being considered low, not suggesting this microorganism migration into the cheese interior.

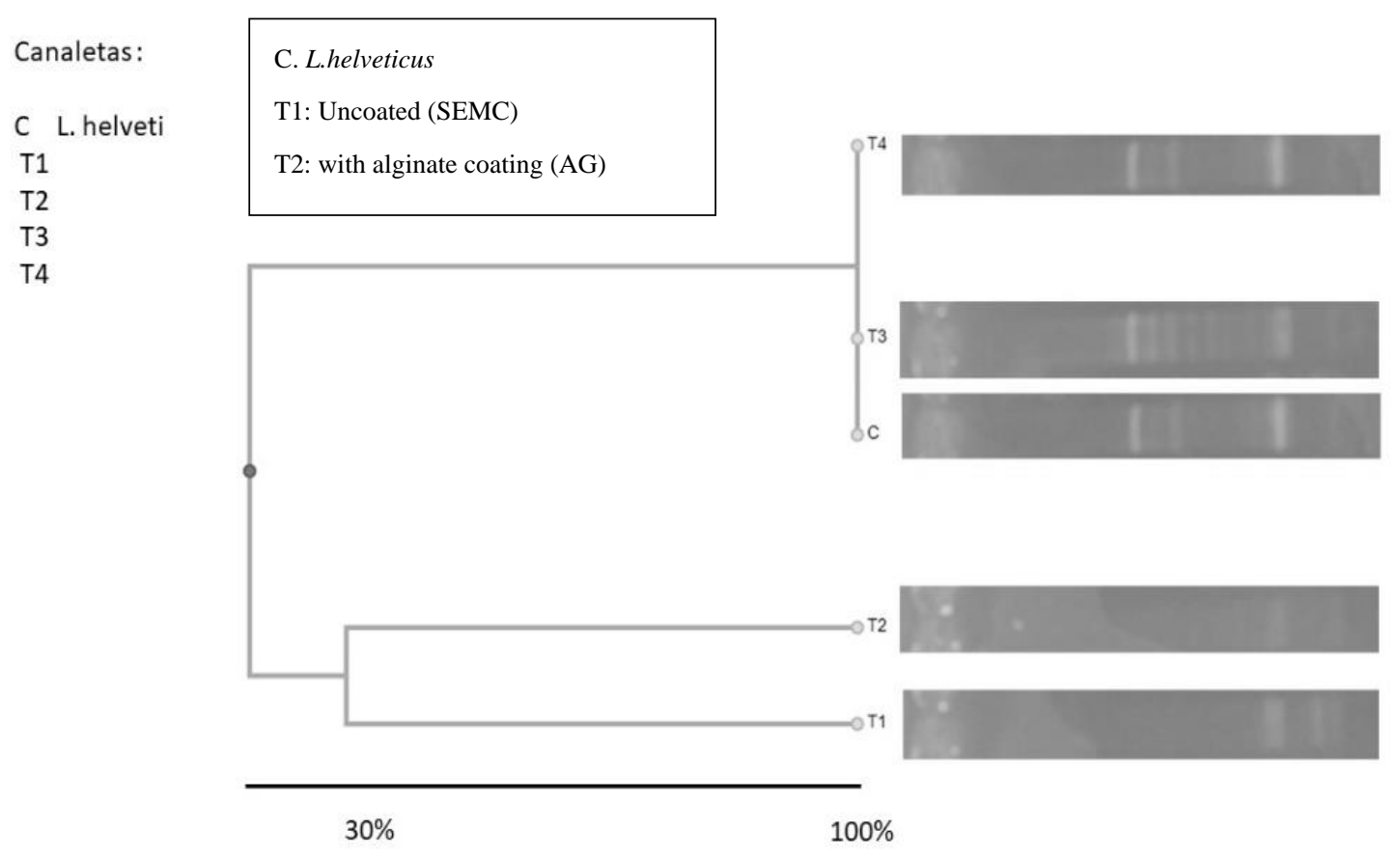

Figure 7. Dendogram of cheeses with and without coating application

In the Andrighetto, Marcazzan, \& Lombardi (2004) study the microorganisms present in the 


\section{Ml Macrothink}

Journal of Agricultural Studies

ISSN 2166-0379

2020, Vol. 8, No. 3

whey for the production of Grana Padano cheese were evaluated by RAPD-PCR, this analysis was useful to evaluate the Lactobacillus and its biodiversity, mainly the L.helveticus. Through the use of the scanning electron microscope it was possible to verify the complete distribution of both microorganisms by the sodium alginate matrix, as shown in Figures 8, 9 and 10. It was also verified that the bacterial cells were incorporated in the cover matrix without alteration of its morphology (rods), being well distributed and able to remain embedded in the coating, finding that the edible sodium alginate coating is a promising matrix for incorporation and delivery of both lactic acid bacteria.

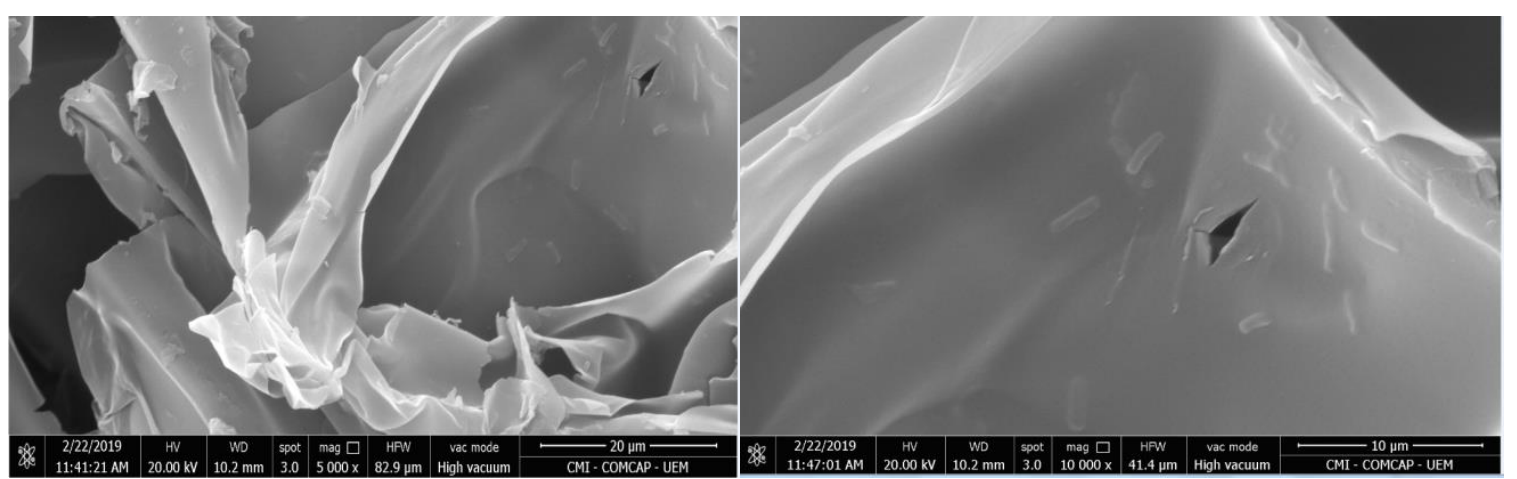

Figure 8. Sodium alginate and L. acidophilus coating 5,000 and 10,000 times

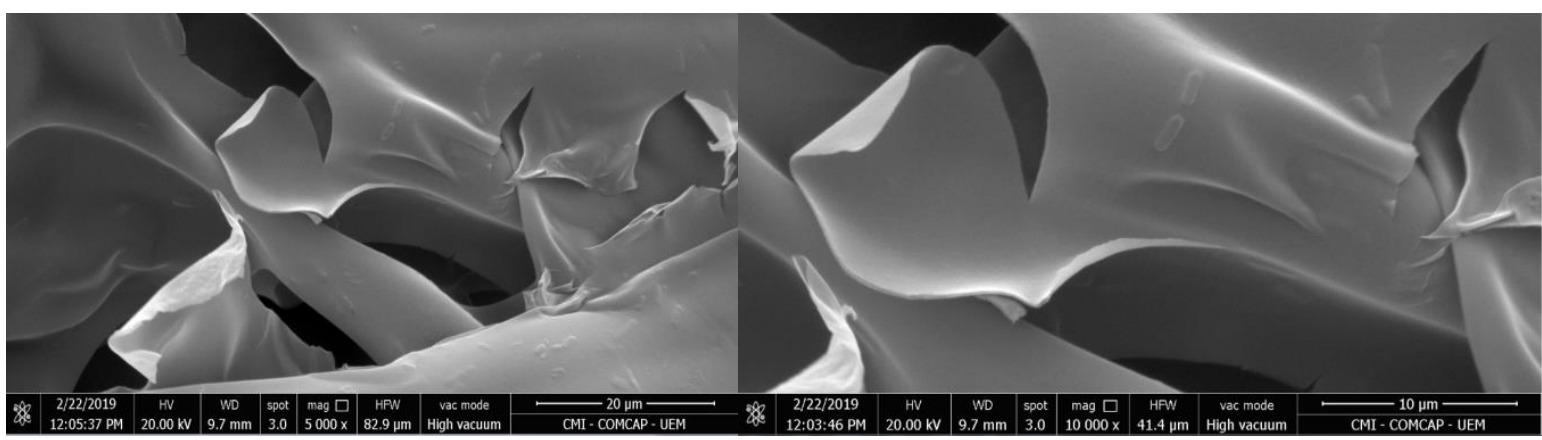

Figure 9. Sodium alginate and L. helveticus coating 5,000 and 10,000 times

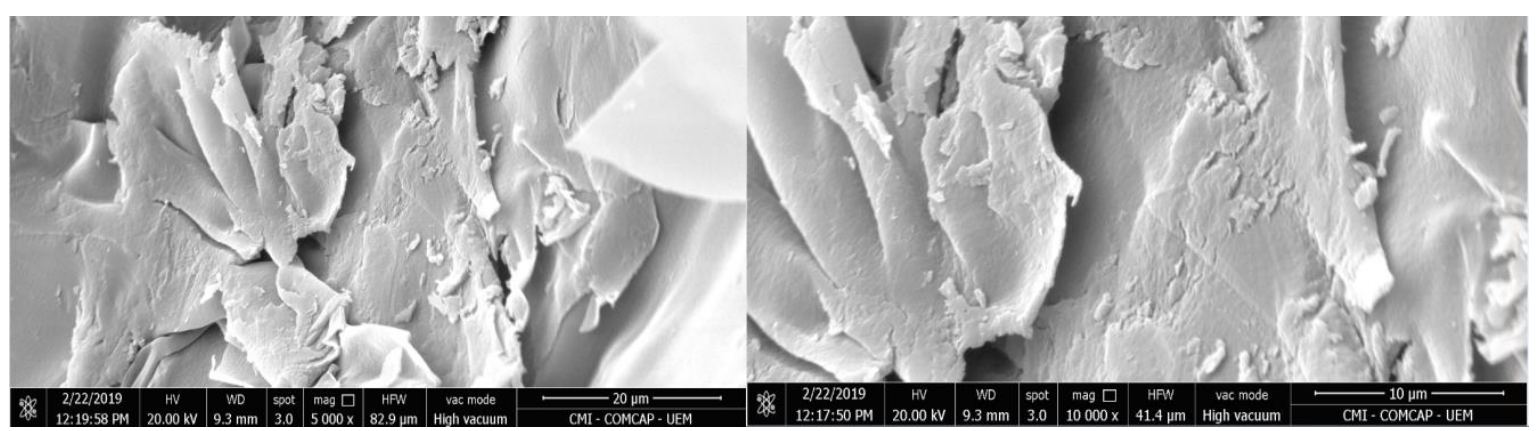

Figure 10. Sodium alginate coating 5,000 and 10,000 times

In the study of Pereira et al. (2016) was observed by scanning electron microscopy analysis of serum protein isolate coatings with bacterial cells, visualization of Bifidobacterium animalis $\mathrm{Bb}-12 \AA$ and $L$. casei-01. The probiotic microorganism incorporation into the edible coatings did not give any noticeable modification to the structural conformation and the 
microorganism presence confirmed by rod-like shapes found in the protein matrix. Thus, the coating is considered as protection to maintain the microorganism viability in a similar way to that observed in this study. The images obtained by the scanning electron microscope (SEM) in the study of Ebrahimi et al. (2018) showed that the polymeric structure of carboxymethyl cellulose (CMC) was homogeneous, uniform and compact, without micropores and the covers with included microorganisms showed a larger number of holes than control coatings, bacterial cells were embedded in the coating matrix (small rod-like shapes) and could result in increased cell protection effects of the coatings and the cross-sectional surfaces of films containing Lactococcus lactis showed smooth surfaces with no cracks, as in the present study (Table 1; AGLA and AGLH were less thick).

\section{Conclusion}

The L. acidophilus and L. helveticus inclusion in edible cheese coverings reduced the total coliforms presence at 10 days. Probiotic bacteria reduced coating flexibility. The possibility of permeability of the microorganism, L. helveticus, is suggested, ensuring that the cover can be a good vehicle for lactic acid bacteria.

\section{Acknowledgements}

The authors thank CNPq (Conselho Nacional de Desenvolvimento Científico e Tecnológico) and National Institute of Science and Technology for Dairy Production Chain (INCT/Leite), Universidade Estadual de Londrina/PR.

\section{References}

American society for Testing and Materials. (1995). Standard test methods for water vapor transmission of material - E-96-95, Philadelphia: ASTM.

American society for Testing and Materials. (1996). Test methods for tensile properties of thin plastics heeting - D-882-91. Annual book of ASTM. Philadelphia: ASTM.

Andrighetto, C., Marcazzan, G., \& Lombardi, A. (2004). Use of RAPD-PCR and TTGE for the evaluation of biodiversity of whey cultures for Grana Padano cheese. Letters in applied microbiology, 38(5), 400-405. https://doi.org/10.1111/j.1472-765X.2004.01504.X

Association of Official Analytical Chemists (2000). Official Methods of Analysis of AOAC International. 17 th ed., Gaithersburg, MD, USA.

Aziz, M. S. A., Salama, H. E., \& Sabaa, M. W. (2018). Biobased alginate/castor oil edible films for active food packaging. LWT - Food Science and Technology, 96, 455-460. https://doi.org/10.1016/j.lwt.2018.05.049

Burns, P., Patrignani, F., Serrazanetti, D., Vinderola, G. C., Reinheimer, J. A., Lanciotti, R., \& Guerzoni, M. E. (2008). Probiotic Crescenza cheese containing Lactobacillus casei and Lactobacillus acidophilus manufactured with high-pressure homogenized milk. Journal of Dairy Science, 91(2), 500-512. https://doi.org/10.3168/jds.2007-0516

Capela, P., Hay, T. K. C., \& Shah, N. P. (2006). Effect of cryoprotectants, prebiotics and 
microencapsulation on survival of probiotic organisms in yoghurt and freeze-dried yoghurt. Food Research International, 39(2),

203-211.

https://doi.org/10.1016/j.foodres.2005.07.007

Costa, M. J., Maciel, L. C., Teixeira, J. A., Vicente, A. A., \& Cerqueira, M. A. (2018). Use of edible films and coatings in cheese preservation: Opportunities and challenges. Food Research International, 107, 84-92. https://doi.org/10.1016/j.foodres.2018.02.013.

da Cruz, A. G., Buriti, F. C. A., de Souza, C. H. B., Faria, J. A. F., \& Saad, S. M. I. (2009). Probiotic cheese: health benefits, technological and stability aspects. Trends in Food Science \& Technology, 20(8), 344-354. https://doi.org/10.1016/j.tifs.2009.05.001

de Oliveira, M. E. G., Garcia, E. F., de Oliveira, C. E. V., Gomes, A. M. P., Pintado, M. M. E., Madureira, A. R. M. F., ... de Souza, E. L. (2014). Addition of probiotic bacteria in a semi-hard goat cheese (coalho): Survival to simulated gastrointestinal conditions and inhibitory effect against pathogenic bacteria. Food Research International, 64, 241-247. https://doi.org/10.1016/j.foodres.2014.06.032

Dos Santos, K. M. O., Vieira, A. D. S., Buriti, F. C. A., do Nascimento, J. C. F., de Melo, M. E. S., Bruno, L. M., ... Todorov, S. D. (2015). Artisanal Coalho cheeses as source of beneficial Lactobacillus plantarum and Lactobacillus rhamnosus strains. Dairy science \& technology, 95(2), 209-230. https://doi.org/10.1007/s13594-014-0201-6

Ebrahimi, B., Mohammadi, R., Rouhi, M., Mortazavian, A. M., Shojaee-Aliabadi, S., \& Koushki, M. R. (2018). Survival of probiotic bacteria in carboxymethyl cellulose-based edible film and assessment of quality parameters. LWT- Food Science and Technology, 87, 54-60. https://doi.org/10.1016/j.lwt.2017.08.066

Eckert, C., Agnol, W. D., Dallé, D., Serpa, V. G., Maciel, M. J., Lehn, D. N., \& de Souza, C. F. V. (2018). Development of alginate-pectin microparticles with dairy whey using vibration technology: Effects of matrix composition on the protection of Lactobacillus spp. from adverse conditions. Food Research International, 113, 65-73. https://doi.org/10.1016/j.foodres.2018.07.001

Fathollahi, I., Hesari, J., Azadmard, S., \& Oustan, S. (2010). Influence of proteolysis and soluble calcium levels on textural changes in the interior and exterior of Iranian UF white cheese during ripening. World Academy Science Engineering and Technology, 66, 844-849.

Food and Agriculture Organization of the United nations; world health Organization. Evaluation of health and nutritional properties of probiotics in food including powder milk with live lactic acid bacteria. Córdoba, 2001. 34p.

Ghanbarzadeh, B., \& Almasi, H. (2011). Physical properties of edible emulsified films based on carboxymethyl cellulose and oleic acid. International journal of biological Macromolecules, 48(1), 44-49. https://doi.org/10.1016/j.ijbiomac.2010.09.014

Gialamas, H., Zinoviadou, K. G., Biliaderis, C. G., \& Koutsoumanis, K. P. (2010). Development of a novel bioactive packaging based on the incorporation of Lactobacillus 
sakei into sodium-caseinate films for controlling Listeria monocytogenes in foods. Food Research International, 43(10), 2402-2408. https://doi.org/10.1016/j.foodres.2010.09.020

Gontard, N., Guilbert, S., \& Cuq, J. L. (1993). Water and glycerol as plasticizers affect mechanical and water vapor barrier properties of an edible wheat gluten film. Journal of food science, 58(1), 206-211. https://doi.org/10.1111/j.1365-2621.1993.tb03246.x

Hayes, M., Coakley, M., O'sullivan, L., \& Stanton, C. (2006). Cheese as a delivery vehicle for probiotics and biogenic substances. AustralianJournalofDairy Technology, 61(2), 132.

Instituto Adolfo Lutz, \& IAL-Instituto Adolfo Lutz. (2008). Normas analíticas, métodos químicos e físicos para análises de alimentos.

Jo, C., Kang, H., Lee, N. Y., Kwon, J. H., \& Byun, M. W. (2005). Pectin-and gelatin-based film: effect of gamma irradiation on the mechanical properties and biodegradation. Radiation Physics and Chemistry, 72(6), 745-750. https://doi.org/10.1016/j.radphyschem.2004.05.045

Kanmani, P., \& Lim, S. T. (2013). Development and characterization of novel probiotic-residing pullulan/starch edible films. Food chemistry, 141(2), 1041-1049. https://doi.org/10.1016/j.foodchem.2013.03.103

Lazzi, C., Bove, C. G., Sgarbi, E., Monica, G., La Gioia, F., Sandra, T., \& Neviani, E. (2009). Application of AFLP fingerprint analysis for studying the biodiversity of Streptococcus thermophilus. Journal of microbiological methods, 79(1), 48-54. https://doi.org/10.1016/j.mimet.2009.07.021

Liserre, A. M., Re, M. I., \& Franco, B. D. (2007). Microencapsulation of Bifidobacterium animalis subsp. lactis in modified alginate-chitosan beads and evaluation of survival in simulated gastrointestinal conditions. Food Biotechnology, 21(1), 1-16. https://doi.org/10.1080/08905430701191064

Ma, D., Jiang, Y., Ahmed, S., Quin, W., \& Liu, Y. (2019). Physical and antimicrobial properties of edible films containing Lactococcus lactis. International Journal of Biological Macromolecules, 141, 378-386. https://doi.org/10.1016/j.ijbiomac.2019.09.006

Mancini, A., Lazzi, C., Bernini, V., Neviani, E., \&Gatti, M. (2012). Identification of dairy lactic acid bacteria by tRNAAla-23S rDNA-RFLP. Journal of microbiological methods, 91(3), 380-390. https://doi.org/10.1016/j.mimet.2012.10.003

Manojlovic, V., Nedovic, V. A., Kailasapathy, K., \& Zuidam, N. J. (2010). Encapsulation of cprobiotics for use in food products. In N. J. Zuidam \& V. A. Nedovic (Eds.), Encapsulation Technologies for Active Food Ingredients and Food Processing. 269-302 https://doi.org/10.1007/978-1-4419-1008-0

Mokarram, R. R., Mortazavi, S. A., Najafi, M. H., \& Shahidi, F. (2009). The influence of multi stage alginate coating on survivability of potential probiotic bacteria in simulated gastric and intestinal juice. Food Research International, 42(8), 1040-1045. https://doi.org/10.1016/j.foodres.2009.04.023 
Ningtyas, D. W., Bhandari, B., Bansal, N., \& Prakash, S. (2019). The viability of probiotic Lactobacillus rhamnosus (non-encapsulated and encapsulated) in functional reduced-fat cream cheese and its textural properties during storage. FoodControl, 100, 8-16. https://doi.org/10.1016/j.foodcont.2018.12.048

Pereira, J. O., Soares, J., Sousa, S., Madureira, A. R., Gomes, A., \& Pintado, M. (2016). Edible films as carrier for lactic acid bacteria. LWT - Food Science and Technology, 73, 543-550. https://doi.org/10.1016/j.lwt.2016.06.060

Phillips, M., Kailasapathy, K., \& Tran, L. (2006). Viability of commercial probiotic cultures (L. acidophilus, Bifidobacterium sp., L. casei, L. paracasei and L. rhamnosus) in cheddar cheese. International journal of food microbiology, 108(2), 276-280. https://doi.org/10.1016/j.ijfoodmicro.2005.12.009

Picot, A., \& Lacroix, C. (2004). Encapsulation of bifidobacteria in whey protein-based microcapsules and survival in simulated gastrointestinal conditions and in yoghurt. International Dairy Journal, 14(6), 505-515. https://doi.org/10.1016/j.idairyj.2003.10.008

Ramos, Ó. L., Pereira, J. O., Silva, S. I., Fernandes, J. C., Franco, M. I., Lopes-da-Silva, J. A., ... Malcata, F. X. (2012). Evaluation of antimicrobial edible coatings from a whey protein isolate base to improve the shelf life of cheese. Journal of dairy science, 95(11), 6282-6292. https://doi.org/10.3168/jds.2012-5478

Randazzo, C. L., Caggia, C., \& Neviani, E. (2009). Application of molecular approaches to study lactic acid bacteria in artisanal cheeses. Journal of Microbiological Methods, 78(1), 1-9. https://doi.org/10.1016/j.mimet.2009.04.001

Rao, A. V., Shiwnarain, N., \& Maharaj, I. (1989). Survival of microencapsulated Bifidobacterium pseudolongum in simulated gastric and intestinal juices. Canadian Institute of Food Science and Technology Journal, 22(4), 345-349. https://doi.org/10.1016/S0315-5463(89)70426-0

Rohlf, F. J. (2000). NTSYS-pc: numerical taxonomy and multivariate analysis system, version 2.1. New York: Exeter Software, 38p.

Sánchez-González, L., Saavedra, J. I. Q., \&Chiralt, A. (2013). Physical properties and antilisterial activity of bioactive edible films containing Lactobacillus plantarum. Food Hydrocolloids, 33(1), 92-98. https://doi.org/10.1016/j.foodhyd.2013.02.011

Sanders, M. E. (2003). Probiotics: considerations for human health. Nutrition reviews, 61(3), 91-99. https://doi.org/10.1301/nr.2003.marr.91-99

SAS. Institute, Statistical Analysis. (2013). System: user guide [CD-ROM]. Version 9.3. Cary (NC): SAS Insitute Inc.

Soukoulis, C., Behboudi-Jobbehdar, S., Yonekura, L., Parmenter, C., \& Fisk, I. D. (2014). Stability of Lactobacillus rhamnosus $G G$ in prebiotic edible films. Food chemistry, 159, 302-308. https://doi.org/10.1016/j.foodchem.2014.03.008 
Sultana, K., Godward, G., Reynolds, N., Arumugaswamy, R., Peiris, P., \& Kailasapathy, K. (2000). Encapsulation of probiotic bacteria with alginate-starch and evaluation of survival in simulated gastrointestinal conditions and in yoghurt. International journal of food microbiology, 62(1-2), 47-55. https://doi.org/10.1016/S0168-1605(00)00380-9

Takahashi, G., Barbosa, H. D., Bergamasco, R., Madrona, G., Tonon, L. C., Yamashita, F., \& Scapim, M. (2017). Development and Active Biodegradable Film Evaluation Incorporated with Oregano Essential Oil and Nanoclay. Chemical Engineering Transactions, 57, 403-408. https://doi.org/10.3303/CET1757068

Yuksekdag, Z. N., \& Aslim, B. (2010). Assessment of potential probiotic-and starter properties of Pediococcus spp. isolated from Turkish-type fermented sausages (sucuk). Journal of Microbiology and Biotechnology, 20(1), 161-168. https://doi.org/10.4014/jmb.0904.04019.

Zottola, E. A., \& Smith, L. B. (1993). Growth and survival of undesirable bacteria in cheese. In Cheese: Chemistry, physics and microbiology (pp. 471-492). Springer, Boston, MA. https://doi.org/10.1007/978-1-4615-2650-6_12

\section{Copyright Disclaimer}

Copyright for this article is retained by the author(s), with first publication rights granted to the journal.

This is an open-access article distributed under the terms and conditions of the Creative Commons Attribution license (http://creativecommons.org/licenses/by/4.0/). 